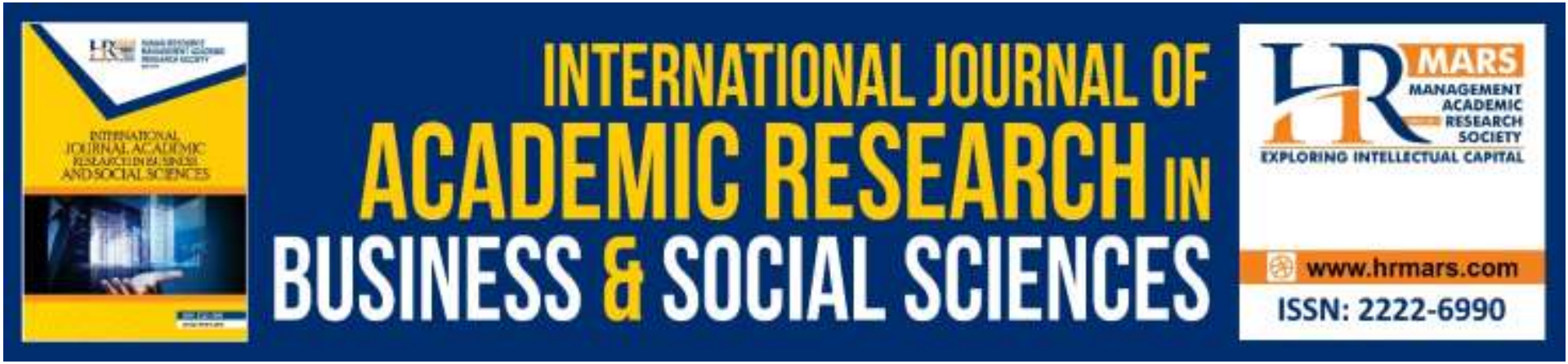

\title{
Moderation Effect of Top Management Support on the Relationship between Customer Reference Marketing and Market Performance
}

Rohana Yaacob, Mas Bambang Baroto, Suzilawati Kamarudin, Nooranida Arifin

To Link this Article: http://dx.doi.org/10.6007/IJARBSS/v9-i7/6263

DOI: $10.6007 /$ IJARBSS/v9-i7/6263

Received: 09 May 2019, Revised: 19 June 2019, Accepted: 30 June 2019

Published Online: 09 July 2019

In-Text Citation: (Yaacob, Baroto, Kamarudin, \& Arifin, 2019)

To Cite this Article: Yaacob, R., Baroto, M. B., Kamarudin, S., \& Arifin, N. (2019). Moderation Effect of Top Management Support on the Relationship between Customer Reference Marketing and Market Performance. International Journal of Academic Research in Business and Social Sciences, 9(7), 1263-1297.

Copyright: @ 2019 The Author(s)

Published by Human Resource Management Academic Research Society (www.hrmars.com)

This article is published under the Creative Commons Attribution (CC BY 4.0) license. Anyone may reproduce, distribute, translate and create derivative works of this article (for both commercial and non-commercial purposes), subject to full attribution to the original publication and authors. The full terms of this license may be seen at: http://creativecommons.org/licences/by/4.0/legalcode

Vol. 9, No. 7, 2019, Pg. 1263 - 1297

http://hrmars.com/index.php/pages/detail/IJARBSS

JOURNAL HOMEPAGE

Full Terms \& Conditions of access and use can be found at http://hrmars.com/index.php/pages/detail/publication-ethics 


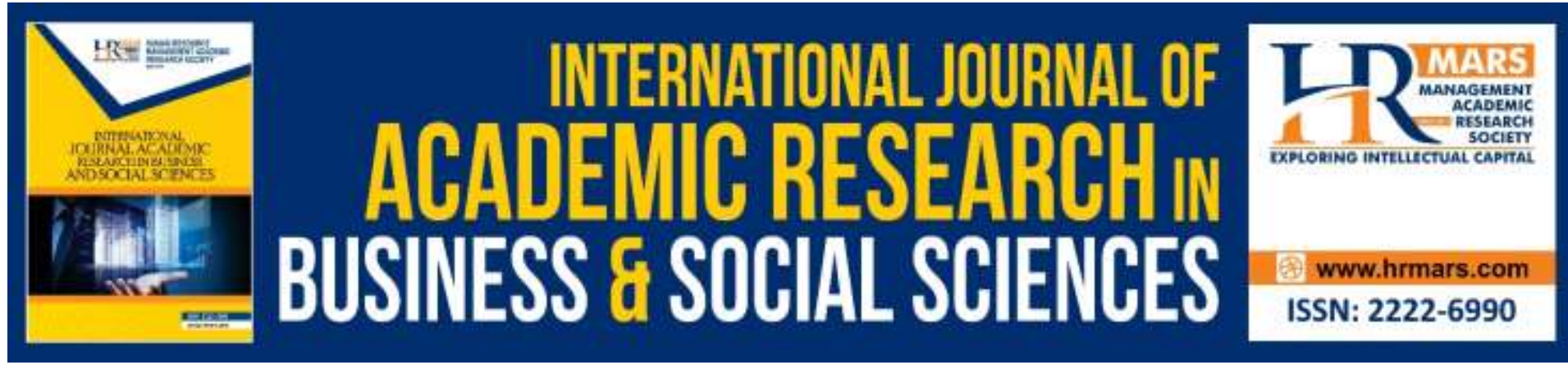

\title{
Moderation Effect of Top Management Support on the Relationship between Customer Reference Marketing and Market Performance
}

\author{
Rohana Yaacob ${ }^{1}$, Mas Bambang Baroto², Suzilawati \\ Kamarudin ${ }^{3}$, Nooranida Arifin ${ }^{4}$ \\ ${ }^{1}$ Azman Hashim International Business School, Universiti Teknologi Malaysia, 54100 Kuala \\ Lumpur, Malaysia. ${ }^{2}$ Azman Hashim International Business School, Universiti Teknologi \\ Malaysia, 54100 Kuala Lumpur, Malaysia. ${ }^{3}$ Azman Hashim International Business School, \\ Universiti Teknologi Malaysia, 54100 Kuala Lumpur, Malaysia. \\ ${ }^{4}$ Department of Biomedical Engineering, Faculty of Engineering, University of Malaya, 50603 \\ Kuala Lumpur, Malaysia. \\ Email: rohana.utm2020@gmail.com, masbambang.kl@utm.my, suzilawati@ibs.utm.my, \\ anidaum@um.edu.my
}

\begin{abstract}
The variables proposed in this study are customer reference marketing (CRM) as independent variable, market performance (MP) as dependent variable, and top management support (TMS) as moderator variable on the relationship between CRM and MP. Based on the framework, the objectives of this study are to investigate the definitions of variables and to define the gap on the relationship between variables. The method used in this study is systematic literature review and the literature are originated from journals in period, 2012 - 2018. Results of the study show that there are lack of studies on the relationship between CRM and MP, and there is contradiction in TMS as moderator on the relationship between $C R M$ and $M P$, where some of the hypotheses results are not significant, and some of them are significant. The results provide significant contribution to the body of knowledge by enriching CRM study, and clarifying the moderating effect of TMS on the relationship between CRM and MP.
\end{abstract}

Keywords: Customer Reference Marketing (CRM), Market Performance (MP) and Top Management Support (TMS)

\section{Introduction}

This study investigated the relationship between three variables namely CRM, MP and TMS. The dependent variable of this study is MP, independent variable of this study is CRM and the moderating variable is TMS. Definition of MP of which containing the financial and nonfinancial (Candi, 2016; Elger, 2007; Kaleka \& Morgan, 2017; Nguyen, Yu, Melewar, \& Gupta, 2016; Pino, Felzensztein, Zwerg-Villegas, \& Arias-Bolzmann, 2016; Seyoum \& Lian, 2018), 
financial (Ahmad \& Jusoh, 2014; Chizari, Mehrjardi, Sadrabadi, \& Mehrjardi, 2016; Roach, Ryman, Jones, \& Ryman, 2018) and non-financial (Aksoy, 2017; Josiassen, Assaf, \& Cvelbar, 2014). This study has chosen definition of MP of which is defined by Aksoy (2017). The reason of choosing definition of MP by Aksoy (2017) is because the definition is focusing only on nonfinancial dimension of performance. The non-financial measures are becoming prerequisite measure of financial dimension of organization and getting more important in measuring performance of company or organization. The operational definition of MP in this study is containing of non-financial dimension which relating to achieve market performance, attract new customers, reaching marketing goals, sales management achieved and securing desired market share.

CRM is defined by many scholars as stated in literature list page 7-9. CRM can be categorized into three unit analyses of empirical observation which are supplier, reference customer and potential customer. The unit analyses based on the past studies are firstly CRM - supplier (Kilian, Greuling, \& Hennigs, 2013; Morgado, 2018; Terho \& Jalkala, 2017), secondly CRM - reference customer (Ruokolainen \& Aarikka-Stenroos, 2016) and finally CRM - potential customer (Morgado \& Castro, 2016). The definition of CRM in this study is a combination of two definitions from Terho and Jalkala (2017), and Killian et al. (2013). The combination is needed because Terho and Jalkala (2017) definitions is focusing on customer orientation, whilst Killian et al. (2013) definition is emphasizing on evoking potential customer. In competitive world today, both orientation and evoking are equally important, hence the combination of both definitions is chosen to become the operational definition of this study. The operational definition of CRM in this study is that CRM is having strong orientation towards customer references is acting as a main role in the marketing efforts and evoking the potential customer by number of references, reputation of reference customers, industry of reference customers, country-of-origin of reference customers, strong focus on technical arguments, strong focus on service arguments, strong focus on the relationship with reference customers, strong focus on products actually manufactured by using the machine, and strong focus on customer benefits.

Meanwhile TMS is defined based on literature list of which stated in literature review page 11-15 whereby that literature review lists is showing that the TMS is having many factors. Scholars from previous studies defined the TMS mostly on the internal matters of the organization (Sheikh, Shahzad, \& Ishak, 2017) (Ahmed, R., \& Azmi bin Mohamed, 2017; Al Shaar, Khattab, Alkaied, \& Manna, 2015; Alam, Masum, Beh, \& Hong, 2016; Almahamid \& Awsi, 2015; Alqahtani, 2017; Birken et al., 2015; Bueno \& Gallego, 2017; Butt, Nawab, \& Zahid, 2018; Dabari \& Saidin, 2014; Dai, Montabon, \& Cantor, 2014; Faber, Geenhuizen, \& Reuver, 2017; Feng \& Zhao, 2014; García-Sánchez, Guerrero-Villegas, \& Aguilera-Caracuel, 2018; Hamdi, Silong, Binti Omar, \& Mohd Rasdi, 2016; Hsu, Liu, Tsou, \& Chen, 2018; Iqbal, Long, Fei, \& Bukhari, 2015; Jia \& Capretz, 2018; John, 2018; Kanwal, Zafar, \& Bashir, 2017; Lee, Shiue, \& Chen, 2016; Lim \& Antony, 2016; Masum, 2015; Mohtaramzadeh, Ramayah, \& Jun-Hwa, 2017; Pasamehmetoglu, Guchait, Tracey, Cunningham, \& Lei, 2017; Prieto-Pastor \& MartinPerez, 2015; Rahikkala, Leppänen, Ruohonen, \& Holvitie, 2015; Rajput, Zahid, \& Najaf, 2018; Santos-Vijande, López-Sánchez, \& Pascual-Fernández, 2015; Shee, Miah, Fairfield, \& Pujawan, 2018; Sheikh et al., 2017; Stirpe, Bonache, \& Trullen, 2015; Wang \& Song, 2017; Yunus, Jailani, Hairuddin, \& Kassim, 2013; Zhang, Wei, \& Zhou, 2018; Zhu, Zou, \& Zhang, 2019) and externalinternal factors (Beitelspacher, Tokman, Adams, \& Glenn Richey, 2012; Lee et al., 2016; Lim \& Antony, 2016; Rajput et al., 2018; Yang \& Zhang, 2018). The definition of TMS in this study 
is referring to definitions of Beitelspacher et al. (2012) which consist of external-internal factors and internal factor. Therefore, the operational definitions of TMS in this study is referring to Beitelspacher et al. (2012) that is TMS is defined as "a combination of external and internal factors which consist of repeatedly tells employees that the success of the organization depends on employees in adapting to market trends, must work with the company's key suppliers to meet customers' future needs by serving customers is the most important task and top management is consistently reinforces the norms and ideals of the organization."

Most of past studies were done in qualitative studies and there was lack of study on the relationship between CRM and MP. However there was a study done by Terho and Jalkala (2017) in mix-method study on the relationship between CRM and selling performance and the result was significant. TMS as moderating effect has insignificant effect on the relationship between customer relationship management and new product performance (Rajput et al., 2018). Meanwhile other scholars found out that TMS as moderating variable has significant effect on the relationship between customer and performance (Beitelspacher et al., 2012; Yang \& Zhang, 2018). Within the period $2014-2018$ (refer page 5-6) of literature lists of MP definitions, the researchers found out that there are three kinds of definitions of MP in general, they are MP with financial and non-financial dimensions, MP with financial dimension and MP with non-financial dimension. Therefore, there is a need to define MP for this particular study.

Within the period 2013 - 2018 of literature lists of CRM definitions, the researchers realized that there are sixteen factors contribute to the definitions of CRM (refer page 7-9). Since there are many factors which contributing to the definitions of CRM, there is a need to define a limited number of factors of which are going to support the operational definitions of CRM in this study. Meanwhile, within the period 2012 - 2018 of literature lists of TMS definitions, the researchers discovered thirty factors contribute to the definitions of TMS. The factors can be found in the literature review page 11-15. Due to the fact that there are many factors of which are contributing to the definitions of TMS, there is a need to define a limited number of factors of which are going to support the operational definitions of TMS in this study.

\section{Problem Statement}

Seyoum and Lian (2018) defined MP by "two contingent factors of firm performance in automotive industry which based on market share and profitability based on financial element." Roach et al. (2018) defined MP by "measuring their performance by growth and profitability in financial term." Aksoy (2017) defined MP by "having non-financial aspect as being related to achieving market performance, attracting new customers, reaching marketing goals, sales management achieved and securing desired market share." Kaleka and Morgan (2017) defined MP by "deriving from sales revenue, market share for financial and sales volume for non-financial." Pino et al. (2016) defined by "achieving customer satisfaction in the term of non-financial, meanwhile total sales and market share in the financial aspect." Candi (2016) defined MP as the "outcome from market share, increase sales to existing customers more than competitors and revenue grow better than the competitors' in the financial aspect and gain more new customers than competitors as the non-financial dimension." The definition of MP developing time to time. 
Morgado (2018) defined CRM as "illustrates the customer relationships which relating to value-creation activities that a firm leverages externally or internally in its marketing efforts is referring to customer references." Terho and Jalkala (2017) defined CRM by "having strong orientation towards CRM and customer references is acting a main role in the marketing efforts." Morgado and de Castro (2016) defined CRM as a "significance of 'reference business. In 'reference businesses', corporate customers typically buy complex, high-tech products or services." Ruokolainen and Aarikka-Stenroos (2016) demonstrate that "CRM referred to the variety of customer referencing type as it conceded towards the quantity of evidence gathered from customer reference list. Moreover, the value in customers stories could draw attention that provide the richness of the evidence." The definition of CRM is developing from time to time.

John (2018) defined TMS as "customer relationship management (CRM) implementation has strong CEO support, top management motivates the employees to live the CRM vision and top management is involved to a large degree in CRM implementation and entrusted with it." García-Sánchez et al. (2018) defined TMS by "top management executive put their effort on information technology (IT). In addition, TMS reflects from the amount of funding for IT, and using technology transfer on the entire of the firm." Zhang et al. (2018) defined TMS as "giving strong encouragement to utilize the energy saving, give support in providing sufficient funding and application of energy saving among the employees day-to-day operation tim." Kanwal et al. (2017) defined TMS as "allocating sufficient facilities in making the task success, initiating the organizational change for effectual implementation to the system and facilitate the system application in the organizational background. TMS also encourage participation from stakeholders for task accomplishment, and always be reachable during emergency situation." Lee et al. (2016) defined TMS as "top management believes that by giving support toward software process improvement (SPI), encouraging employees to share their SPI-related input, entrust the necessity aid to employees are important during SPI implementation. In addition, top management must shows their enthusiasm to the contented employees in sharing their SPI-related knowledge among colleague is also crucial during SPI implementation." Beitelspacher et al. (2012) defined TMS as "the company repeatedly tells employees that the success of the organization depends on employees in adapting to market trends, must work with the company's key suppliers to meet customers' future needs by serving customers is the most important task and top management is consistently reinforces the norms and ideals of the organization." The definition TMS is developing time to time.

Morgado (2018) defined the relationship between customer reference marketing (CRM) and potential customer, Terho and Jalkala (2017) defined the relationship between CRM and selling performance, Morgado and de Castro (2016) defined (2016) defined the relationship between CRM and capital buying decision, Ruokolainen and Aarikka-Stenroos (2016) defined the relationship between CRM and sales argument, Aarikka-Stenroos and Makkonen (2014) defined the relationship between CRM and experience-based information and Kilian et al. (2013) defined the relationship between CRM and perceived supplier's competencies. There is lack of literature on the relationship between CRM and MP.

Rajput et al. (2018) defined the moderation effect of TMS on the relationship between customer relationship management and new product performance and the result was not supported. Yang and Zhang (2018) defined the moderation effect of TMS on the relationship between customer focus and non-financial performance and the result was not significant. Beitelspacher et al. (2012) defined the moderation effect of TMS on the relationship between 
customer orientation and market performance and the result was positively moderates. Hence there is a contradiction on the literature of moderation effect of TMS.

\section{Research Question}

Beside the need of defining the operational definitions above, this study also found that, there are lack of studies on the relationship between CRM and MP, and the understanding about various practices and function of CRM is remain unclear. In addition, this study also found that there is a contradiction on the moderating effect of TMS on the relationship between CRM and MP. Referring to the above findings, the research questions of this study are:

1) What are the operational definitions of CRM, MP and TMS?

2) Is there any gap from the past studies for the relationship between CRM to MP?

3) Is there any gap from the past studies for the moderating effect of TMS on the relationship between CRM and MP?

Therefore, the researchers are going to do literature review, on the next section, by using the systematic literature review method. "Systematic reviews, as the name implies, typically involve a detailed and comprehensive plan and search strategy derived a priory, with the goal of reducing bias by identifying, appraising, and synthesizing all relevant studies on a particular topic." Scope of this study are; to define the operational definition of the variables, to review the literature on relationship between CRM and MP, and to investigate the moderating effect of TMS on the relationship between CRM and MP.

\section{Literature Review \\ Definition of Variables \\ Market Performance}

Open systems practised by organizations could expose to change where the change can cause of the subsequent change in another subsystem and this changes could effect of the organizations performance (Wangui, Faith, \& Aketch, 2019). According to theory of performance (ToP), performance has two dimensions, they are financial and non-financial. Category of decreasing of cost is under category of financial dimension. Meanwhile, increasing quality, increasing in capability, increasing in knowledge, increasing in skills and increasing of identity and motivation are categories under non-financial dimension.

According to the definitions above, there are scholars who define market performance as the outcome from sales revenue (Kaleka \& Morgan, 2017), profitability (Nguyen et al., 2016; Seyoum \& Lian, 2018), revenue growth (Candi, 2016; Roach et al., 2018), return of investment (Nguyen et al., 2016), share price (Ahmad \& Jusoh, 2014), Tobin's Q (Ahmad \& Jusoh, 2014; Chizari et al., 2016) and sales determiner or market growth (Chizari et al., 2016; Nguyen et al., 2016) in defining market performance in term of financial dimension.

On the other hand for non-financial dimension, scholars defined market performance based on market share (Candi, 2016; Kaleka \& Morgan, 2017; Nguyen et al., 2016; Pino et al., 2016; Seyoum \& Lian, 2018), reaching market goal (Aksoy, 2017), customer satisfaction (Nguyen et al., 2016; Pino et al., 2016), sales volume (Kaleka \& Morgan, 2017), new customer (Aksoy, 2017; Candi, 2016), size output (Josiassen et al., 2014), progress in production (Josiassen et al., 2014), human resource management (Josiassen et al., 2014), achieved target (Aksoy, 2017), sales management (Aksoy, 2017), and securing desired market (Aksoy, 2017).

Referring to the below list of literature, Table 1, the researchers have chosen performance definition defined by Aksoy (2017). The reason of choosing definition of MP by 
Aksoy (2017) is because the definition is focusing only on non-financial dimension of performance. And, non-financial measures are becoming prerequisite measure of financial dimension of organization. Meanwhile Damanpour, Walker and Avellaneda (2009) stated that the performance with non-financial in firms embrace innovation to gain a competitive advantage that will ultimately lead to superior performance. Therefore, operational definition for market performance of this study derived from Aksoy (2017), MP are activities such as attract new customers, reaching marketing goal, sales management, achieved and securing market share, to achieve market performance.

Table 1: List of literature of MP

\begin{tabular}{ll}
\hline Authors & Definitions \\
\hline Seyoum & MP is defined by "two contingent factors of firm performance in \\
and Lian & automotive industry which based on market share and profitability based \\
(2018) & on financial element."
\end{tabular}

Roach et al. MP is defined by "measuring their performance by growth and (2018) profitability in financial term."

Aksoy MP is defined by "having non-financial aspect as being related to achieving (2017) market performance, attracting new customers, reaching marketing goals, sales management achieved and securing desired market share."

Kaleka and MP is defined by "deriving from sales revenue, market share for financial Morgan and sales volume for non-financial."

(2017)

Pino et al. MP is defined by "achieving customer satisfaction in the term of non(2016) financial, meanwhile total sales and market share in the financial aspect."

Candi MP is defined as the "outcome from market share, increase sales to (2016) existing customers more than competitors and revenue grow better than the competitors' in the financial aspect and gain more new customers than competitors as the non-financial dimension."

Nguyen et MP is defined as "market growth, market share, return on investment, and al. profitability as financial performance indicators. Meanwhile for customer (2016) performance, has been adapted customer satisfaction for non-financial dimension."

Chizari et MP is defined as "market value and Tobin's $Q$ in financial measurement." al. (2016) 


\begin{tabular}{ll}
\hline Authors & Definitions \\
\hline $\begin{array}{l}\text { Ahmad and } \\
\text { Jusoh }\end{array}$ & $\begin{array}{l}\text { MP is defined as an "outcome from Tobins's Q and share prices in financial } \\
\text { (2014) }\end{array}$ \\
$\begin{array}{ll}\text { Josiassen et." } \\
\text { al. (2014) }\end{array}$ & $\begin{array}{l}\text { MP is defined by "technical efficiency as an output and input in hotel } \\
\text { market context. The terms of output and input have been used in their } \\
\text { study which similar to non-financial dimension for total hotel revenue and } \\
\text { other services as the output and meanwhile for (input): number of } \\
\text { employees, cost of material and services, and other operational cost." }\end{array}$ \\
\hline
\end{tabular}

\section{Customer Reference Marketing}

CRM is also recognised as "customer advocacy marketing, "customer evidence marketing," "customer testimonial marketing" and "customer reference marketing". In business world complexity, firms are using CRM to attract potential buyers. In order to organize references visit, firms are inviting potential buyers to communicate references on firms' websites and customer magazines to show products or services delivered to reference customers. This is happening in the sales situation (Terho \& Jalkala, 2017).

Morgado (2018) stated that a few academic studies focused about CRM. Nonetheless, CRM is yet to become a conventional research topic since there were a little number of published peer-reviewed articles dedicated to CRM. Publication on this topic has been extended for twenty years and was peaking in 2008 (Morgado, 2018).

Client references or known as CRM has become a useful tool in marketing services and business product in the industry, especially for new start-up organizations. Ruokolainen and Aarikka-Stenroos (2016) defined the references by a "value" which can be assessed in varying terms. Firstly, the criteria of valuable reference is referring on the how much the valuable input of the first reference can provide to the organization. Second criteria, is by the increased of good reputation is required to convince the next customers.

The exploratory case study done by Morgado (2018) showed that there are three sources in constructing value for their future customers. The first source is regarding the supplier qualification process. This supplier qualification process is crucial part to organization due to establish their supplier competency, and be able to forecast their return on investments. The second source of constructing the value is pinpointing new business necessity. This activity generally happens when supplier is introducing a new technology. The technology is considered to be launched for the business solution, and yet to be adopted by the customers. The final source of value is referring to the organizational learning process, which derived from customers reference's success stories. In this situation, the supplier are the key source for organization learning process.

Meanwhile, the relationship between CRM and capital buying seems insignificant and not in the character of the acquisition for capital goods in the context of a reference business (Morgado \& de Castro, 2016). Jalkala and Salminen (2010) in Morgado (2018) define CRM as "the customer relationships and related value-creation activities that a firm leverages externally or internally in its marketing efforts". Salminen (2001) in Morgado and de Castro (2016) stated that CRM is important in capital equipment industries. This statement is supported by (Salminen \& Möller, 2004), who claimed that references play a key role in capital 
equipment bidding processes. The relevance of CRM is important to high-tech and unpredictable market, and been argued by scholars since the relevancy of CRM is increased the potential customers' perceived-risk.

Terho and Jalkala (2017) conducted a cross-sectional survey towards 944 salespeople and managers in 43 firms from various industries, namely information and communication technology (ICT), materials, machinery and equipment and defined CRM activities. The CRM activities are composing of utilizing customer references in marketing communications, using customer references in sales communications, utilizing evidence from customer references to communicate the value of the products and services, applying customer references to concretize on how customers can benefit from the products and services, communicating to customer references as a proof of the functionality of the products and services, and lastly, ensuring that firms salespeople use customer references in their sales communications. Based on the explanation above, Terho and Jalkala (2017) defined as CRM is having strong orientation towards CRM and customer references is acting as a main role in the marketing efforts.

Salminen and Möller (2006) and, Anderson and Wynstra (2010) in Ruokolainen and Aarikka-Stenroos (2016) demonstrate that CRM is having different customer referencing types, the other customer reference types are characterized by two types, these are 1) acknowledges customer reference lists that focusing to the amount of evidence; and 2) valuein-use stories that emphasize the richness of the evidence. Kilian et al. (2013) defined CRM as potential customer and supplier. Reference descriptions that contain positive experiences from former customers foster higher perceptions of a supplier's competency.

CRM can be categorized into three unit analyses of empirical observation which are supplier, reference customer and potential customer. Then, the past studies on CRM can be categorized into unit analysis of supplier (Kilian et al., 2013; Morgado, 2018; Terho \& Jalkala, 2017), reference customer (Ruokolainen \& Aarikka-Stenroos, 2016) and potential customer (Morgado \& de Castro, 2016).

According to the unit analyses above, CRM has some elements they are value-creation activities that a firm leverages externally or internally (Morgado, 2018), environment that are related to the effectiveness of CRM (Aarikka-Stenroos \& Makkonen, 2014; Morgado \& de Castro, 2016), market uncertainty raise the relevance of customer references (Morgado \& de Castro, 2016), focusing to the amount of evidence (Ruokolainen \& Aarikka-Stenroos, 2016), value-in-use stories that emphasize the richness of the evidence (Ruokolainen \& AarikkaStenroos, 2016), evoke the potential customer by number of references (Kilian et al., 2013), evoke the potential customer by reputation of reference customers (Kilian et al., 2013), evoke the potential customer by industry of reference customer (Kilian et al., 2013), evoke the potential customer by country-of-origin of reference customers (Kilian et al., 2013), evoke the potential customer by strong focus on technical arguments (Kilian et al., 2013), evoke the potential customer by strong focus on service arguments (Kilian et al., 2013), evoke the potential customer by strong focus on the relationship with reference customers (Kilian et al., 2013), evoke the potential customer by strong focus on products actually manufactured by using the machine (Kilian et al., 2013), evoke the potential customer by strong focus on customer benefits (Kilian et al., 2013), strong orientation towards CRM (Terho \& Jalkala, 2017) and acting as a main role in the marketing efforts (Terho \& Jalkala, 2017).

From past literatures above, there are many elements of CRM has been defined in past studies (see Table 2). This study highlighted elements introduce by Terho and Jalkala 
(2017), and Kilian et al. (2013). The reason of choosing elements introduced by Kilian et al. (2013) because their research context is having very close characteristics to the context of this study, e.g., prosthetic and orthotic industry. Prosthetic and orthotic industry requires expensive machine, take months to produce, mostly customized products and suppliers who more knowledge in respect to underlying technologies than customers. In addition, the reason of choosing elements introduced by Terho and Jalkala (2017) is because of their research context is on complex product offering and in proving the functionality of new technologies and very similar to the context of this study.

Based on the above important elements introduced by Terho and Jalkala (2017), and Kilian et al. (2013), the operational definition of CRM in this study is defined by the number of reference, the importance of reference customer reputation, industry, country of origin and acting as a main role in the marketing efforts, besides it should have strong focus on technical arguments, service arguments, relationship with reference customers, products actually manufactured by using the machine, customer benefits, and orientation towards CRM.

Table 2: List of literature of CRM

\begin{tabular}{|c|c|c|c|c|c|}
\hline \multirow[t]{2}{*}{$\begin{array}{l}\text { Authors/ } \\
\text { Years }\end{array}$} & \multirow[t]{2}{*}{ Definitions } & \multirow[t]{2}{*}{$\begin{array}{l}\text { Research } \\
\text { Method }\end{array}$} & \multicolumn{3}{|c|}{$\begin{array}{l}\text { Unit Analysis } \\
\text { of Empirical } \\
\text { Observation }\end{array}$} \\
\hline & & & $\begin{array}{c}\text { Supplie } \\
r\end{array}$ & $\begin{array}{l}\text { Reference } \\
\text { Customer }\end{array}$ & $\begin{array}{c}\text { Potentia } \\
\text { I } \\
\text { Custome } \\
r\end{array}$ \\
\hline
\end{tabular}

Morgado Jalkala and Salminen (2010) in Qualitativ $X$

(2018) Morgado (2018) "illustrates the e customer relationships which relating to value-creation activities that a firm leverages externally or internally in its marketing efforts is referring to customer references."

Terho and CRM has been defined by "having Jalkala strong orientation towards CRM Mixed $\quad X$ (2017) and customer references is acting methods as a main role in the marketing efforts."

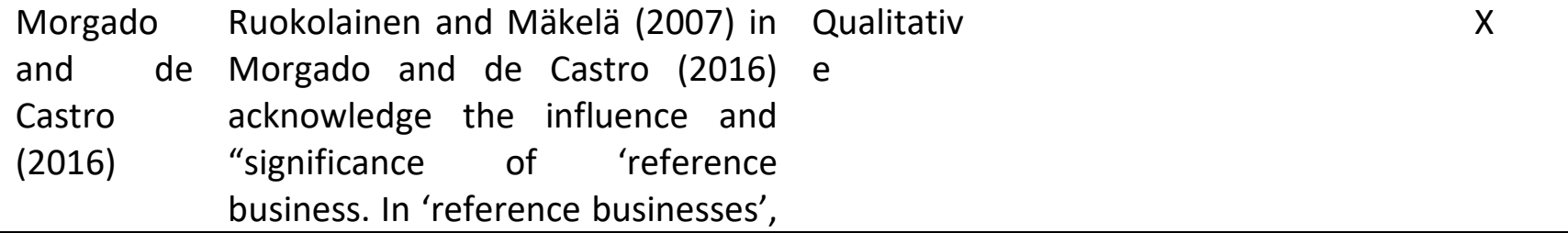




\begin{tabular}{|c|c|c|c|c|c|}
\hline \multirow[t]{2}{*}{$\begin{array}{l}\text { Authors/ } \\
\text { Years }\end{array}$} & \multirow[t]{2}{*}{ Definitions } & \multirow[t]{2}{*}{$\begin{array}{l}\text { Research } \\
\text { Method }\end{array}$} & \multicolumn{3}{|c|}{$\begin{array}{l}\text { Unit Analysis } \\
\text { of Empirical } \\
\text { Observation }\end{array}$} \\
\hline & & & $\begin{array}{c}\text { Supplie } \\
r\end{array}$ & $\begin{array}{l}\text { Reference } \\
\text { Customer }\end{array}$ & $\begin{array}{c}\text { Potentia } \\
\text { I } \\
\text { Custome } \\
r\end{array}$ \\
\hline & $\begin{array}{l}\text { corporate customers typically buy } \\
\text { complex, high-tech products or } \\
\text { services." }\end{array}$ & & & & \\
\hline $\begin{array}{l}\text { Ruokolaine } \\
\mathrm{n} \quad \text { and } \\
\text { Aarikka- } \\
\text { Stenroos } \\
\text { (2016) }\end{array}$ & $\begin{array}{l}\text { Salminen and Möller (2006) in } \\
\text { Ruokolainen and Aarikka-Stenroos } \\
\text { (2016) demonstrate that "CRM } \\
\text { referred to the variety of customer } \\
\text { referencing type as it conceded } \\
\text { towards the quantity of evidence } \\
\text { gathered from customer reference } \\
\text { list. Moreover, the value in } \\
\text { customers stories could draw } \\
\text { attention that provide the richness } \\
\text { of the evidence." }\end{array}$ & $\begin{array}{l}\text { Qualitativ } \\
\mathrm{e}\end{array}$ & & $x$ & \\
\hline $\begin{array}{l}\text { Aarikka- } \\
\text { Stenroos } \\
\text { and } \\
\text { Makkonen } \\
(2014)\end{array}$ & $\begin{array}{l}\text { Aarikka Stenroos and Makkonen } \\
\text { (2014) define "CRM that the } \\
\text { environment characteristic is } \\
\text { affecting the customer's } \\
\text { information search strategy, a } \\
\text { buyer's previous experience, and } \\
\text { perceptions of the sources' } \\
\text { credibility" (Bunn, 1993a, b; } \\
\text { Brashear-Alejandro et al., 2010)." }\end{array}$ & $\begin{array}{l}\text { Qualitativ } \\
\mathrm{e}\end{array}$ & & & $x$ \\
\hline $\begin{array}{l}\text { Kilian et al. } \\
(2013)\end{array}$ & $\begin{array}{l}\text { CRM is defined by the "number of } \\
\text { reference, the importance of } \\
\text { reference customer reputation, } \\
\text { industry and country of origin, } \\
\text { besides it should have strong focus } \\
\text { on technical arguments, service } \\
\text { arguments, relationship with } \\
\text { reference customers, products } \\
\text { actually manufactured by using the } \\
\text { machine, and on customer } \\
\text { benefits." }\end{array}$ & $\begin{array}{l}\text { Qualitativ } \\
\mathrm{e}\end{array}$ & $x$ & & \\
\hline
\end{tabular}




\section{Top Management Support}

Many past studies have highlighted the success of the organizations due to effective top management support. Among the scholars are Young and Jordan (2008), who agreed that TMS is the most important critical success factor for project success. This statement also is supported by later study by Feng and Zhao (2014) that manifest the TMS in the context of manufacturing firms in China. TMS is elucidated by the support of the employees received from top management to improve the supply chain management. Aside from that, a study done by Yunus et al. (2013) at Klang Valley, Malaysia, towards a chosen of public-private organizations found that the TMS plays a vital role in achieving the vision of the organizations. Based on this study, the vision of the organizations could be attained by encouraging the change of communication and focusing towards the desired vision. Hence, this study shares the same interpretation of the importance of effective TMS in determining the successful marketing strategy of the organization.

Top management is the highest ranking executives with titles such as chairman, chief executives officer, managing director and other similar level of them. Top management is known as the person that responsible for the entire organizations. Numerous studies have been conducted in identifying the roles of top management and its support for the success of the business. However, the relationship between effective TMS practices in regard to CRM has yet to be determined.

Several studies have revealed that TMS is defined as giving strongly supports the adoption of the energy saving, giving effort to provide stable and sufficient funding and other resources for the energy-saving measures implementation and operation (Zhang et al., 2018). Top management also actively encourages employees to save energy in their daily work in the industries of mining, processing of petroleum, manufacture of chemical products, manufacture of general purpose, machinery, wholesale and retail trade in China (Zhang et al., 2018).

Recently, a quantitative study showed relationship between customer relationship management and new product performance which moderated by TMS. TMS has been defined as the role of CEO as the top management which is measured by attendance at project meeting, involvement in information requirement analysis, involvement in reviewing consultant's recommendation, involvement in decision-making and involvement in monitoring project which has been practised in ISO certified firms of several industries namely in food, banking, textile, pharmaceuticals, and footwear industries in Pakistan (Rajput et al., 2018).

Yang and Zhang (2018), defined TMS as top management believes that the relationship with customers is very important, considers that the exchange and sharing of valuable information with customers is a key part for company and requests for increased resources are mostly satisfied by top management. This discovery is based on industry of electronics, machinery and transportation components in various countries namely Brazil, China, Finland, Germany, Israel, Italy, Japan, South Korea, Spain, Sweden and Taiwan. Hsu et al. (2018) explained that TMS as having a clarity of the task-focused and objectives, executed to ensure the task success, participated in the whole of the task activities, contributed the ideas to the task and cherished the positive recommendations from their employees in Taiwan such as Information technology (IT) firms, computers and peripheries, 
semiconductors, photonics, electronic components, telecommunications and network apparatus.

Based on past studies, there are various elements which defined by scholars, whereby the elements of TMS are top management participate in developing technology project champions (García-Sánchez et al., 2018), top management should provide funding for the task ( Shaar et al., 2015; Faber et al., 2017; García-Sánchez, García-Morales, \& Bolívar-Ramos, 2015; García-Sánchez et al., 2018; Shee et al., 2018; Wang \& Song, 2017), top management should support of using technology in (Alam et al., 2016; Alqahtani, 2017; Bueno \& Gallego, 2017; Faber et al., 2017; García-Sánchez et al., 2015, 2018; Mohtaramzadeh et al., 2017; Shee et al., 2018; Sheikh et al., 2017; Wang \& Song, 2017; Zhang et al., 2018), top management should attend project meeting (Jia \& Capretz, 2018; Rajput et al., 2018), top management should involve in information requirement (Rajput et al., 2018), top management should involve in reviewing recommendation (Rajput et al., 2018; Wang \& Song, 2017), top management should involve in decision making (Rajput et al., 2018), top management should involve in monitoring project (Hsu et al., 2018; Rahikkala et al., 2015; Rajput et al., 2018; Santos-Vijande et al., 2015), top management support (Hamdi et al., 2016; John, 2018; Lim \& Antony, 2016; Prieto-Pastor \& Martin-Perez, 2015; Santos-Vijande et al., 2015; Stirpe et al., 2015; Wang \& Song, 2017; Yunus et al., 2013), top management should motivate the employees (Butt et al., 2018; Dai et al., 2014; John, 2018; Lee et al., 2016; Mohtaramzadeh et al., 2017), top management should involve in task implementation (Almahamid \& Awsi, 2015; Dabari \& Saidin, 2014; John, 2018; Kanwal et al., 2017; Lim \& Antony, 2016; Yunus et al., 2013), top management should involve in system implementation (Kanwal et al., 2017), top management believe that customer is important (Beitelspacher et al., 2012; Yang \& Zhang, 2018), top management should commit to project success (Hsu et al., 2018; Iqbal et al., 2015; Rahikkala et al., 2015), top management should provide resources to project (Ahmed, R., \& Azmi bin Mohamed, 2016; Almahamid \& Awsi, 2015; Dabari \& Saidin, 2014; Feng \& Zhao, 2014; Hamdi et al., 2016; Hsu et al., 2018; lqbal et al., 2015; Prieto-Pastor \& Martin-Perez, 2015; Santos-Vijande et al., 2015; Yunus et al., 2013), top management should value the employees' ideas and suggestions (Hsu et al., 2018), top management should support in human resources (Masum, 2015; Wang \& Song, 2017), top management should host the project meetings (Jia \& Capretz, 2018), top management should solve project problems (Jia \& Capretz, 2018; Pasamehmetoglu et al., 2017), top management should reward staff for innovation and creativity (Al Shaar et al., 2015; Faber et al., 2017), top management should encourage knowledge sharing (Lee et al., 2016; Lim \& Antony, 2016), top management should create an enthusiastic atmosphere during the project (Hamdi et al., 2016), top management should devote a lot of time to the project (Hamdi et al., 2016), top management should established effective communication (Ahmed, R., \& Azmi bin Mohamed, 2016, 2017; Rahikkala et al., 2015; Yunus et al., 2013), top management should be considerate of subordinate's feeling (Pasamehmetoglu et al., 2017), top management should encourage innovation implementation (Birken et al., 2015), top management should improve the supply chain management (Feng \& Zhao, 2014), "top management should ensure that the success of the organization depends on employees in adapting to market trends (Beitelspacher et al., 2012), top management should work with the company's key suppliers to meet customers' future needs (Beitelspacher et al., 2012) and top management should reinforce the norms and ideals of the organization (Beitelspacher et al., 2012)." 
From the above list of literature, tabulated in Table 3, this study highlighted elements introduced by Beitelspacher et al. (2012), because in their article the TMS is a moderator of relationship between customer orientation and market performance. That relationship between customer orientation and MP is the closest relationship between CRM and MP of this study.

Operational definition for TMS in this study is defined as "repeatedly tells employees that the success of the organization depends on employees in adapting to market trends, must work with the company's key suppliers to meet customers' future needs by serving customers is the most important task and top management is consistently reinforces the norms and ideals of the organization."

Table 3: List of literature of TMS

\begin{tabular}{ll}
\hline Authors & Definitions \\
\hline John & TMS has been defined of which that "customer relationship management (CRM) \\
(2018) & implementation has strong CEO support, top management motivates the \\
& employees to live the CRM vision and top management is involved to a large \\
& degree in CRM implementation and entrusted with it."
\end{tabular}

García-Sánchez et al. (2018)

Zhang et al. (2018)

Shee et al. (2018)

Rajput et al. (2018)

Butt et al. (2018)

Hsu et al. (2018)
Byrd and Davidson (2003) in García-Sánchez et al. (2018) defined "TMS demonstrates by top management executive put their effort on information technology (IT). In addition, TMS reflects from the amount of funding for IT, and using technology transfer on the entire of the firm."

TMS defined as "giving strong encouragement to utilize the energy saving, give support in providing sufficient funding and application of energy saving among the employees day-to-day operation time."

TMS has been defined as "top management as a leader of technology in the firm, be prepared to take any possibility of the affect in "cloud" application and having tendency to spend a certain fund in information and communication system."

TMS has been defined as "CEO involvements for most top management activities, namely; attend project meeting, involve information requirement analysis, and assessing the consultant advice, decision making process and monitor projects in the organization."

Young and Jordan (2008) in Butt et al. (2018) defined "TMS is referred to aged study that was applicable for those employees who will be benefited from the TMS only and obligatory to increase the employee production in many firms. However this is not reasonable for profession of medical doctors."

TMS is defined as "having a clarity of the task-focused and objectives, executed to ensure the task success, participated in the whole of the task activities, 


\begin{tabular}{ll}
\hline Authors & Definitions \\
\hline & contributed the ideas to the task and cherished the positive recommendations \\
& from their employees."
\end{tabular}

Yang and Zhang (2018)

Mohtaramzade $h$ et al.

(2018)

Jia and Capretz (2018)

Kanwal et al. (2017)

Sheikh et al. (2017)

Bueno and Gallego

(2017)

Wang and Song (2017)

Alqahtani (2017)
TMS is defined as "top management believes that the relationship with customers is very important, considers that the exchange and sharing of valuable information with customers is a key part for company."

TMS is defined as "top management always try to equip the requisite of resources for execution, implementation and practices of e-commerce in order to gain competitive advantage. Top management repeatedly educate their employees to keep up with the latest information, and retain for bringing more practices via online in order to fulfil customer future needs."

TMS is defined as "top management often attends the project meetings, often hosts the project meetings and solves project problems in time."

TMS is defined as "allocating sufficient facilities in making the task success, initiating the organizational change for effectual implementation to the system and facilitate the system application in the organizational background. TMS also encourage participation from stakeholders for task accomplishment, and always be reachable during emergency situation."

TMS is defined as "support the adoption, allocate sufficient resource, having knowledge of the benefit and encourage employees to use the new technology in their daily tasks."

TMS is defined as "top management is interested in enterprise resource planning-open source software (OSS-ERP), understands the importance of OSSERP, supports the OSS-ERP, consider the OSSERP as strategically important, understands OSS-ERP opportunities, keeps the pressure on operating units to work with OSS-ERP. This OSS-ERP is regarded as high priority by top management whereby the top management is very supportive of OSS-ERP use in employees' job."

TMS is defined as "top managers provide sufficient support in BIM training, provide sufficient support in BIM consulting, provide sufficient financial support for BIM, provide sufficient support in human resources and top managers provide sufficient support in technology."

TMS is defined as "top management encourages staff to use a wiki for jobrelated tasks, top management is aware of the benefits that can be achieved with the use of a wiki and top management recognises the staff efforts in using a wiki for their tasks." 
Authors Definitions

Faber et al. (2017)

Pasamehmetog lu et al.

(2017)

Lee et al.

(2016)

Hamdi et al.

(2016)

Alam et al.

(2016)

Lim and Antony

(2016)

Ahmed and

Mohamad

(2016)
TMS is defined as "giving rewards to staff for eHealth innovation and creativity, strongly encourages the use of eHealth, providing adequate resources (time and money) available for eHealth, developing a vision on eHealth and do evaluation between the management and medical professionals about eHealth impact takes place on a regular basis."

TMS is defined as "top management supports always available for the staff, values staff contribution, really cares about the staff well-being, cares about staff opinions, takes pride in staff accomplishment, top management is considerate to the staff's feelings and is willing to extend him/himself to help staff to resolve service error."

TMS is defined as "top management believes that by giving support toward software process improvement (SPI), encouraging employees to share their SPIrelated input, entrust the necessity aid to employees are important during SPI implementation. In addition, top management must shows their enthusiasm to the contented employees in sharing their SPI-related knowledge among colleague is also crucial during SPI implementation."

TMS is defined as "top management supported the project, top management devoted a lot of time to the project, top management provided adequate resources to the project and top management created an enthusiastic atmosphere during the project process."

TMS is defined as "top management equip the required resources for implementing e-business application, and keep reminding that employees should be more responsive to contender initiatives with regard to e-business. Apart from that, top management repeatedly tells employees to adapt relating to internet market trends, conduct more of their business practices via online to fulfil customer future needs, and follow the latest development in internet technology."

TMS is defined as "top management uncompromising support, management commitment, and top management involvement, top management on board with the adoption, top management is the ones who initiate and push the SPC programme."

TMS is defined as "giving sufficient resources and create productive communication with project team member. Furthermore, TMS needs to communicate regarding the possibility system changes, and implication during the project implementation, to sell the project to the rest of the organization, and having effective communication, and support from stakeholder to boost the efficiency in organization. TMS also responsible to facilitate system modification and must be accessible during crises." 


Authors Definitions

Birken et al. (2015)

Prieto-Pastor and MartinPerez (2015)

Rahikkala et al. (2015)

Masum

(2015)

Stirpe et al. (2015)

Almahamid and Awsi (2015)

Al Shaar et al. (2015)

García-

Sa'nchez et al. (2015)
Klein, Conn \& Sorra (2001) in Birken et al. (2015) defined TMS as "top management's effort to build a condition which inspire the innovation implementation, namely; carrying out the implementation policies and procedures (IP\&P) to educate employees to use an innovation (i.e., training), provide an assistance (i.e., funding), reward (i.e., incentive), and having practical communication between the top management and middle manager regarding the problem occurs, and succeed-related with the innovation implementation."

TMS is defined as "the employees in this organization feel it is easy to approach their supervisor, employees in this organization receive encouragement and support from their supervisors, employees in this organization have access to resources that they need to do their work, and employees in this organization have the guidance and help that they need to do their work."

TMS is defined as "involvement of top management in software cost estimation (SCE), the method used by top management in SCE, significant of the method used, and the estimation success point of view of SCE."

TMS is defined as "top management has a strategic plan for Electronic Human Resource Management (e-HRM), allocated adequate resources for e-HRM, and top management is aware of the advantages of e-HRM."

TMS has been defined as "top management has put all its support behind the new practice, stressed the importance of the new practice and encouraged us to embrace the new practice."

TMS is defined as "top management is providing leadership for ERP Project Implementation and necessary resources for ERP project."

Jung, Chow and Wu (2003), Elenkov, Judge and Wright (2005), Makri \& Scandura (2010), Denti and Hemlin (2012), Refaie, Ghnaimat and Ko (2011) and Ryan and Tipu (2013) in Al Shaar et al. (2015) have defined as TMS as "top management is committed to create the necessary infrastructure to support innovation activities such as creating the appropriate educational environment for employees, providing financial support for training programs, and promoting teamwork."

TMS is defined as "top management cultivates information and communication technology project champions, ensures adequate funding of information and communication technology research and development, and restructures work processes to leverage opportunities for information and communication technology in the organisation." 


\begin{tabular}{ll}
\hline Authors & Definitions \\
\hline Iqbal et al. & TMS is defined as "top management holds an important role as project leader \\
(2015) & in ensuring the project success, and delegating necessary jurisdiction over the \\
& project resources. Besides, top management responsible to amend their \\
& strategies and policies for the attainment of project accomplishment, and must \\
& aware that their effort could lead the way of success and inversely. Thus, TMS \\
& fasten the virtuous about the future of a project."
\end{tabular}

Santos-Vijande et al. (2015)

Dabari and Saidin

(2014)

Dai et al. (2014)

Feng and Zhao (2014)

Yunus et al. (2013)

Beitelspacher et al. (2012)
Cooper and Kleinschmidt (1995) in Santos-Vijande et al. (2015), "the hotel's management supported the development of the new service, allocated the necessary resources for the development of the new service, and created a multidisciplinary team responsible for development."

Barton, Shenkir, \& Walker (2002) and, Kleffner, Lee and McGannon (2003) in Dabari and Saidin (2014) defined "TMS has the paramount responsibility towards the risk management activities which commence enterprise risk management (ERM) program to safeguarding the firm's asset, and apply the constructive resources, structure and risk management culture in enhancing the ERM implementation." Beasley, Clune and Hermanson (2005) in Dabari and Saidin (2014) posit that having effective implementation of risk management is required involvement from TMS."

TMS is defined as "environmental initiatives are motivated by the examples top management provides, requirements made from senior management, and people at the top of our firm."

TMS is defined as "top management commits supply chain management efforts to improve the supply chain management, puts high priority upon the chief supply chain management officer, considers highly on supply chain management department's views, emphasizes the supply chain management function's strategic role, considers new product development to be a vital part of our corporate strategy, and requests for increased resources."

TMS plays a vital role in achieving the vision of the organizations. Based on this study, the vision of the organizations could be attained by encouraging the change of communication and focusing towards the desired vision. Hence, this study shares the same interpretation of the importance of effective TMS in determining the successful marketing strategy of the organization.

TMS is defined as "the company repeatedly tells employees that the success of the organization depends on employees in adapting to market trends, must work with the company's key suppliers to meet customers' future needs by serving customers is the most important task and top management is consistently reinforces the norms and ideals of the organization." 


\section{CRM to MP}

According to Terho and Jalkala (2017), CRM was having a close relationship with firms' selling performance. Morgado (2018), in his study was not focusing on the relationship between CRM and performance; and their exploration towards single case study that provides evidence for the value of customer references to potential customers in business market. Meanwhile Ruokolainen and Aarikka-Stenroos (2016) were focusing on how a start-up companies can strengthen their argumentation power and their persuasiveness of their scarce customer referencing. Kilian et al. (2013) were extending Jalkala and Salminen (2010) research approach by concentrating on the intended effects on potential customers. Based on the above literature, the researchers concluded that there is a lack of study on the linkage between CRM to MP. And, the above discussion is providing the hypothesis as stated below.

Hypothesis 1: CRM has positive relationship with MP

\section{TMS Moderates Relationship between CRM and MP}

The finding from Rajput et al. (2018) found that TMS as a moderating variable between customer relationship management and new product performance. The result test of hypothesis of TMS as moderating variable from Rajput et al. (2018) was not significant. Meanwhile another scholar from Yang and Zhang (2018) found out that TMS as moderating variable between customer focus and (a) financial performance and (b) non-financial performance, had the hypotheses results of significant. The findings from Yang and Zhang (2018) research stated above were supported by Beitelspacher et al. (2012) that TMS as moderator variable. TMS as moderator variable on the relationship between customer orientation and MP are having significant effect. The above discussion is providing the hypothesis as stated below.

Hypothesis 2: TMS moderate the relationship between CRM and MP

\section{Conceptual Framework}

The conceptual framework as shown in Figure 1 below is showing that CRM is having direct relationship to performance and the effect of top management support (TMS) moderation on the relationship between CRM and MP are having contradicting on their hypotheses where they are having research gaps.

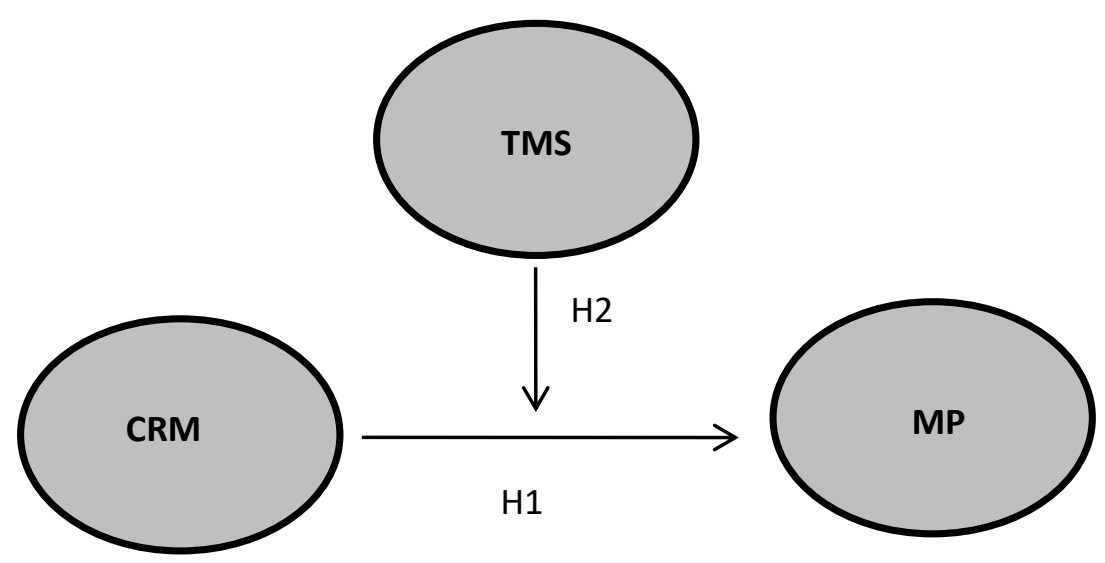

Figure 1 : Conceptual Framework 


\section{Theories}

The above conceptual framework is supported by resource based view (RBV). Besides, RBV is also supporting independent variable of CRM and moderating variable of TMS. Meanwhile theory of performance (ToP) is supporting the dependent variable of MP.

\section{Resourced Based View (RBV)}

The RBV is the underpinning theory which supporting the relationship between CRM and MP, and moderating effect of TMS between relationship of CRM and MP. One of the most critical tasks for business owners is continuously seeking for the best strategy that is able to enhance firm performance in total.

Hitt, Carnes and Xu (2016) suggest that further application of RBV, proposed by Barney (1991) could add richness in management research, and has the potential to produce multiple contributions for the management field. The RBV argues that, the sustained competitive advantage is generated by the unique bundle of resources at the core of the organization. Besides, RBV states that organization develops and improves its business from the capabilities and resources they currently possess (Dollinger, 1999). The term resources and capabilities were thought to be anything that able to serve as strength and weaknesses for the organization. The main focus of the RBV is to stimulate an organization to achieve superior performance over other organizations (Alvarez \& Barney, 2007). This superior performance is attained through examining and acquiring unique resources of the organization.

The RBV affirms that, organization performs better than others in the industry through the resources they acquired. The core message behind the RBV is that, the sustainable competitive advantage is attained through the use of tangible and intangible resources and assets by the organization executive (Barney, 1991). Intangible resources are mostly composed of interrelated resources that are difficult to isolate and treat separately which causes difficulty in clearly specifying the boundaries of a resource and its transfer.

The tangible resources include human resources, plants, equipment and others, while intangible resources include corporate secrets and reputations as embedded in the organizational culture. Distinctive organizational culture has been considered as a resource for competitive advantage (Barney, 1991). Therefore, it can be explained that employees' performance and employee's personality traits are parts of tangible resources while organizational culture which comprises organization unique secrets, mission, values and others are parts of intangible resources. Based on this understanding, both tangible and intangible resources possessed by the organization could boost organization performances. Terho and Jalkala (2017) have classified the business strategies in order to effectively explore the relationship that exist between strategy and other variables. Generally, RBV is an analytical and operational framework for creating and being sustaining competitive advantage. The RBV has been used in theoretical foundation to investigate the role of market capabilities in creating and maintaining competitive advantage (Barney, J. B., Ketchen Jr, D. J., \& Wright, 2011; Kozlenkova, Samaha, \& Palmatier, 2014).

RBV of which is producing dynamic capabilities perspective has made possible to offer a better framework for complex instability market, which pursue the continuity reconfiguration of renewal of the firms (Ambrosini, Bowman, \& Collier, 2009; Winter, 2003). The homogenization of market capabilities with variety of other roles have spearheaded to the improving establishment of the market capabilities which play as an integral function in initiate the dynamic capabilities (Fang \& Zou, 2009; Menguc \& Auh, 2006). Dynamic marketing 
capabilities is different from other dynamic capabilities which essentially concerned with the collection of assimilation of market knowledge, and the unity of dynamic marketing capabilities with the rest of the firms. Dynamic marketing capabilities has been translated as the "human capital, social capital and the cognition of managers involved in the creation, use and integration of market knowledge and marketing resources in order to match and create market and technological change" (Bruni \& Verona, 2009).

\section{RBV - Supporting the CRM}

CRM initially was defined as a firm's efforts to use current or previous customer relationships and related value-creation activities in the firm's marketing activities of which are targeted at potential customers and other stakeholders (Terho \& Jalkala, 2017). CRM researches had been conducted in a qualitative field (Aarikka-Stenroos \& Makkonen, 2014; Kilian et al., 2013; Morgado, 2018; Morgado \& de Castro, 2016; Ruokolainen \& Aarikka-Stenroos, 2016), and mix-method study by Terho and Jalkala (2017). Kohli and Jaworski (1990) and, Ulaga and Reinartz (2011) defined the operational definition of CRM by adopting qualitative studies, theories-in-use approach with the objective of integrating theory-based and field-based views of reference marketing (Glaser \& Strauss, 1999). This reference marketing specifies the activities that make up companies' CRM.

There had been quite long period, that there is no established rigorous constructs exist in CRM (Anderson, Narus, \& Rossum, 2006; Ballantyne, Frow, Varey, \& Payne, 2011; Melnyk, Bititci, Platts, Tobias, \& Andersen, 2013; Payne \& Frow, 2005; Reinartz, Krafft, \& Hoyer, 2004; Terho, Haas, Eggert, \& Ulaga, 2012). Recently, Terho and Jalkala (2017) contributed research on firstly, CRM based on the theory field-study finding and CRM definition, and secondly, a novel measure for CRM. These contributions are crucial for the business marketing subject as numerous studies have highlighted the prime importance of customer references in business marketing.

\section{Theory of Performance (ToP)}

Elger (2007) has defined Theory of Performance (ToP) which is relating to six foundational concepts to illustrate performance and its performance improvement. In performing the valued outcome, a performer as an individual or a group of people such as company is going to engage in a collaborative effort. The progress of company performance would be depending on six components; condition, degree of knowledge, degree of skills, degree of identity, personal factors and fixed factors. There are three principles to improve the performance effectively which include performer's mind set, immersion in enriching environment setting and engagement in a reflective practice (Elger, 2007).

The performance definition is concluded that there are two dimensions of performance in ToP which dimension indicated that category of decreasing of cost is category under financial dimension. Meanwhile, dimension that category of increasing quality, increasing in capability, increasing in knowledge, increasing in skills and increasing of identity and motivation are categorized under non-financial dimension.

\section{RBV- Supporting the TMS}

Hunt and Mogan (1995), referred to RBV, had developed resource-advantage theory which viewed resources as tangible and intangible entities. Firm utilized the tangible and intangible 
entities to develop marketplace offerings in a productive and effective manner for targeted market segments.

Business-to-business research and practice, view the operant resources aligned with intangible resources as described in the resource-advantage theory which include skills and knowledge of employees, knowledge of customers, competitors, suppliers, and other stakeholders as well as organizational core competence, processes, brand equity, relationships with competitors, suppliers, and customers (Morgan \& Hunt, 1999).

According to Beitelspacher et al. (2012), there are two operant resources as moderators, top management support and relationship quality with suppliers, as they relate to management and partner buy-in. These two moderators are called interconnected operant resources due to these resources are internal to the organization and critical to the firm's external relationships with suppliers. TMS is the organization's leadership team, and it has a commitment to cultivating the firm's competitive advantages.

\section{Methodology}

For the purposed of answering research questions, this study is using a systematic literature review by collecting selected articles of sound journals such as Emerald, Elsevier, JSTOR, ScienceDirect, Google Scholars, and Scopus journals. The outcomes of the review of various literature studies answered all the research questions and achieved all the research objectives. The selected literature were reviewed by synthesizing and discussing them. The literature review has addressed the definition of CRM, MP and TMS, the lack of study on the relationship between CRM and MP and finally the contradiction result among previous studies on TMS as moderator variable on the relationship between CRM and MP.

The definition of variables are defined by collecting related articles of CRM (five years period), MP (five years period), and TMS within seven years period. Within that period, this study has found broad definitions of CRM, MP and TMS. The broad definitions, then, are synthesized and discussed the selected definition for this study. This process is followed by discussion on why the researchers came to that particular selected definitions. Finally, in Table 4, the process ended by stating down the operational definitions of CRM, MP and TMS.

Table 4: Operational definitions for variables

\begin{tabular}{ll}
\hline Variable & \multicolumn{1}{c}{ Operational Definitions } \\
\hline MP & MP of this study derived from Aksoy (2017) whereby the definition is containing \\
of non-financial dimension which relating to achieve market performance, attract \\
new customers, reaching marketing goals, sales management achieved and \\
securing desired market share.
\end{tabular}

CRM CRM in this study is a combination of both definitions from Terho and Jalkala (2017) and Kilian et al. (2013). Thus, the operational definition in this study is defined by the number of reference, the importance of reference customer reputation, industry, country of origin and acting as a main role in the marketing efforts, besides it should have strong focus on technical arguments, service arguments, relationship with reference customers, products actually manufactured by using the machine, customer benefits, and orientation towards CRM. 
Variable Operational Definitions

TMS TMS in this study adopted from from Beitelspacher et al. (2012) has been clarified as the company repeatedly tells employees that the success of the organization depends on employees in adapting to market trends, must work with the company's key suppliers to meet customers' future needs by serving customers is the most important task and top management is consistently reinforces the norms and ideals of the organization.

To review the relationship between CRM and MP, the researchers collected articles from (various) journals within five years period. Most of the collected articles were done by qualitative research method, and only one article done by Terho and Jalkala (2017) was in mix-method study.The previous qualitative researches have shown the relationship between CRM and various variables, but not the relationship between CRM and performance. Meanwhile Terho and Jalkala (2017) was doing the research on the relationship between CRM and selling performance and the result was significant. From both of those findings, the researchers concluded that there is a lack of study on the relationship between CRM and MP. The literature on the CRM and performance variables are listed in Table 5 below.

Table 5: The relationship between CRM and Performance

\begin{tabular}{|c|c|c|c|c|c|}
\hline No & Scholar/Year & $\begin{array}{l}\text { Independent } \\
\text { Variable }\end{array}$ & $\begin{array}{l}\text { Dependent } \\
\text { Variable }\end{array}$ & Result & $\begin{array}{l}\text { Research } \\
\text { Method }\end{array}$ \\
\hline 1. & $\begin{array}{l}\text { Morgado } \\
(2018)\end{array}$ & CRM & $\begin{array}{l}\text { Potential } \\
\text { customer }\end{array}$ & $\begin{array}{l}\text { There is a } \\
\text { relationship }\end{array}$ & Qualitative \\
\hline 2. & $\begin{array}{l}\text { Terho and Jalkala } \\
\text { (2017) }\end{array}$ & CRM & $\begin{array}{l}\text { Selling } \\
\text { performance }\end{array}$ & Significant & Mix-method \\
\hline 3. & $\begin{array}{l}\text { Morgado and de } \\
\text { Castro (2016) }\end{array}$ & CRM & $\begin{array}{l}\text { Capital } \\
\text { buying } \\
\text { decision }\end{array}$ & $\begin{array}{l}\text { There is no } \\
\text { relationship }\end{array}$ & Qualitative \\
\hline 4. & $\begin{array}{l}\text { Ruokolainen and } \\
\text { Aarikka-Stenroos } \\
\text { (2016) }\end{array}$ & CRM & $\begin{array}{l}\text { Sales } \\
\text { argument }\end{array}$ & $\begin{array}{l}\text { There is a } \\
\text { relationship }\end{array}$ & Qualitative \\
\hline 5. & $\begin{array}{l}\text { Aarikka-Stenroos and } \\
\text { Makkonen } \\
\text { (2014) }\end{array}$ & CRM & $\begin{array}{l}\text { experience- } \\
\text { based } \\
\text { information }\end{array}$ & $\begin{array}{l}\text { There is a } \\
\text { relationship }\end{array}$ & Qualitative \\
\hline 6. & $\begin{array}{l}\text { Kilian et al. } \\
\text { (2013) }\end{array}$ & CRM & $\begin{array}{l}\text { perceived } \\
\text { supplier's } \\
\text { competencies }\end{array}$ & $\begin{array}{l}\text { There is a } \\
\text { relationship }\end{array}$ & Qualitative \\
\hline
\end{tabular}


Meanwhile, in the process of literature review on the moderating effect of TMS on the relationship between CRM and MP, the researchers collected literatures within seven years period. The literatures collected in this period are very limited, because the researchers focused on the literature where TMS as a moderator on the relationship between CRM and performances. The literature list, Table 6 , showed contradiction on the moderating effect of TMS on the relationship between customer relationship management and new product performance, the result was not supported (Rajput et al., 2018), moderating effect of TMS on the relationship between customer focus and (a) non-financial performance, the result was not significant and moderating effect of TMS on the relationship between customer focus and (b) financial performance, the result was significant (Yang \& Zhang, 2018), and the moderating effect of TMS on the relationship between (a) customer orientation and market performance, the result positively moderate, and the moderating effect of TMS on the relationship between (b) service culture and market performance, the result was positively moderate The list of literature on the past studies of TMS as moderator is shown in the Table 6.

Table 6: Moderating Effect of TMS

\begin{tabular}{|c|c|c|c|c|c|}
\hline $\begin{array}{l}\mathbf{N} \\
\mathbf{0} .\end{array}$ & Scholar/Year & $\begin{array}{l}\text { Independent } \\
\text { Variable }\end{array}$ & Moderator & $\begin{array}{l}\text { Dependent } \\
\text { Variable }\end{array}$ & Result \\
\hline 1. & $\begin{array}{l}\text { Rajput et al. } \\
(2018)\end{array}$ & $\begin{array}{l}\text { Customer } \\
\text { relationship } \\
\text { management }\end{array}$ & TMS & $\begin{array}{l}\text { new product } \\
\text { performance }\end{array}$ & $\begin{array}{l}\text { Not } \\
\text { supported }\end{array}$ \\
\hline \multirow[t]{2}{*}{2.} & $\begin{array}{l}\text { Yang and } \\
\text { Zhang } \\
(2018)\end{array}$ & $\begin{array}{l}\text { Customer } \\
\text { focus }\end{array}$ & TMS & $\begin{array}{l}\text { non-financial } \\
\text { performance }\end{array}$ & Not Significant \\
\hline & & & & $\begin{array}{l}\text { Financial } \\
\text { performance }\end{array}$ & Significant \\
\hline \multirow[t]{2}{*}{3.} & $\begin{array}{l}\text { Beitelspacher } \\
\text { et al. (2012) }\end{array}$ & $\begin{array}{l}\text { i)Customer } \\
\text { orientation }\end{array}$ & TMS & $\begin{array}{l}\text { Market } \\
\text { Performance }\end{array}$ & $\begin{array}{l}\text { Positively } \\
\text { moderate }\end{array}$ \\
\hline & & $\begin{array}{l}\text { ii)Service } \\
\text { culture }\end{array}$ & & & $\begin{array}{l}\text { Positively } \\
\text { moderate }\end{array}$ \\
\hline
\end{tabular}

\section{Results and Discussion \\ Findings}

The findings which have been found from the research have shown that there are operational definitions for MP, CRM and TMS as can be seen in Table 4. The findings have also shown that there are lack of studies on the relationship between CRM and MP in quantitative and qualitative, the details are shown in Table 5. Besides, the findings have shown the contradiction of the moderating effect of TMS, as can be seen on Table 6 . 


\section{Discussion}

These discussion on variables and linkages between variables.

\section{Variable Definitions}

\section{Market Performance (MP)}

Based on Table 1, it can be seen there are various definitions for MP. The researchers have chosen performance definition defined by Aksoy (2017). The definition is chosen because the definition is focusing for non-financial dimension of performance whereby non-financial measures are becoming prerequisite measure of financial dimension of organization. According to Damanpour et al. (2009) defined that the performance with non-financial in firms will embracing innovation which will ultimately lead to superior performance. Thus, operational definition for MP of this study derived from Aksoy (2017), consisting of activities such as attract new customers, reaching marketing goal, sales management, achieved and securing market share, to achieve market performance.

\section{Customer Reference Marketing (CRM)}

Referred to Table 2, it can be seen there are many elements of CRM has been defined in past studies. This study highlighted elements introduce by Terho and Jalkala (2017), and Kilian et al. (2013). These elements have been chosen from Kilian et al. (2013) because their research context is having similar characteristics to the context of this study, e.g., prosthetic and orthotic industry. The context of Prosthetic and orthotic industry requires very expensive machine, take several months to produce, mostly customized products and suppliers who more knowledge in respect to underlying technologies than customers. In addition, the reason of choosing elements introduced by Terho and Jalkala (2017) is because of their research context is on complex product offering and in proving the functionality of new technologies and very similar to the context of this study.

These important elements introduced by Terho and Jalkala (2017), and Kilian et al. (2013), have been used to defined the operational definition of CRM in this study. Therefore, CRM is defined by the number of reference, the importance of reference customer reputation, industry, country of origin and acting as a main role in the marketing efforts, besides it should have strong focus on technical arguments, service arguments, relationship with reference customers, products actually manufactured by using the machine, customer benefits, and orientation towards CRM.

\section{Top Management Support (TMS)}

Illustrated in Table 3 (page 11-15), and it can be seen the list of literature for TMS. However, this study highlighted elements introduced by Beitelspacher et al. (2012), because in their article the TMS is a moderator of relationship between customer orientation and market performance. That relationship between customer orientation and MP is the closest relationship between CRM and MP of this study.

Therefore, the operational definition for TMS in this study is defined as repeatedly tells employees that the success of the organization depends on employees in adapting to market trends, must work with the company's key suppliers to meet customers' future needs by serving customers is the most important task and top management is consistently reinforces the norms and ideals of the organization. 


\section{Linkages}

\section{CRM and MP}

Based on the Table 5, it can be concluded that there is a lack of studies on the relationship between CRM and MP. The past qualitative researches stated in Table 5 have shown that there are relationship between CRM and various variables (the relationship between CRM and potential customer, CRM and capital buying decision, CRM and sales argument, CRM and experience-based information, CRM and perceived supplier's competencies). And yet they did not do the relationship between CRM and MP. On the other hand, there is only one mixmethod study on the relationship between CRM and selling performance. From the above findings, it can be concluded that is lack of study on the relationship between CRM and MP.

\section{Moderation Effect of TMS between CRM And MP}

The finding for TMS as a moderator between CRM and MP is shown that linkage between CRM and MP is having contradiction where TMS is not giving effect to CRM and performance (Rajput et al., 2018). Meanwhile Yang and Zhang (2018) found that TMS is having significant effect with customer focus and performance. Similar finding for Beitelspacher et al. (2012) found that TMS is having significant moderating effect on the relationship between customer orientation and market performance.

\section{Conclusion}

The findings of this study are as the following;

1. Past studies on TMS as moderator on the relationship between CRM and MP has found a gap. This finding is answering the research question number three "is there any gap from the past studies for the moderating effect of TMS on the relationship between CRM and MP?"

- The gap for TMS as moderator variable on the relationship between CRM and MP is having contradiction in hypotheses results from the previous literature. There are two significant moderating effect of TMS on the relationship between CRM and performances, and, there are three insignificant moderating effect of TMS on the relationship between CRM and performances.

- $\quad$ TMS has the moderation effect between CRM and MP in the context of retail supply chain in USA. And, TMS has no moderation effect of TMS on the relationship between CRM and MP in the context of food, banking, textile, pharmaceuticals, footwear, electronics, machinery and transportation components.

2. This study found no gap, but the lack of study on linkages between CRM and MP. The finding is not answering the research question number two "is there any gap from the past studies for the relationship between CRM and MP?"

- Study on CRM is still dearth. There is rare literature on CRM and only relationship between CRM and MP.

3. The operational definitions of variables of MP, CRM and TMS, and these are answering the research question number one "what are the operational definitions of CRM, MP and TMS?"

- Operational definition of MP is containing of non-financial dimension which relating to achieve market performance, attract new customers, reaching marketing goals, sales management achieved and securing desired market share. 
- Operational definition of CRM is defined by the number of reference, the importance of reference customer reputation, industry, country of origin and acting as a main role in the marketing efforts, besides it should have strong focus on technical arguments, service arguments, relationship with reference customers, products actually manufactured by using the machine, customer benefits, and orientation towards CRM. Hence, the operational definition of CRM is operable in ICT, healthcare, financials, industrial (process technology equipment business) and mechanical engineering industry.

- Operational definition of TMS is clarified as the company repeatedly tells employees that the success of the organization depends on employees in adapting to market trends, must work with the company's key suppliers to meet customers' future needs by serving customers is the most important task and top management is consistently reinforces the norms and ideals of the organization.

This operational definitions of MP, CRM, and TMS are going to be addressed to the high technology industries based companies in Malaysia, to fulfil PhD thesis.

\section{Recommendations}

1. Since there is contradiction on the moderation effect of TMS on the relationship between CRM and MP, there should be more research on the moderation effect of TMS between CRM and MP in the context of retail supply chain in other country rather than USA, to test whether or not the result would be significant. Meanwhile, there should be more research on the moderation effect on TMS between CRM and MP in the context of food, banking, textile, pharmaceuticals, footwear, electronics, machinery and transportation components, to test whether or not the result would be insignificant.

2. There is lack of study on the relationship between CRM and MP because the linkage is newly being researched. It is recommended for researchers to do research in the relationship between CRM and MP.

3. In this study, CRM is defined by the number of reference, the importance of reference customer reputation, industry, country of origin and acting as a main role in the marketing efforts, besides it should have strong focus on technical arguments, service arguments, relationship with reference customers, products actually manufactured by using the machine, customer benefits, and orientation towards CRM. And, the definition is operable in ICT, healthcare, financials, industrial (process technology equipment business) and mechanical engineering industry. Researchers should follow the developing the definition of CRM and its context.

\section{Theoretical Contribution}

This research found on new definition of customer reference marketing (CRM) whereby CRM is defined by the number of reference, the importance of reference customer reputation, industry, country of origin and acting as a main role in the marketing efforts, besides it should have strong focus on technical arguments, service arguments, relationship with reference customers, products actually manufactured by using the machine, customer benefits, and orientation towards CRM. This operational definition is a combination of CRM defined by Terho and Jalkala (2017) and Kilian et al. (2013). This study is contributing to the definition of CRM. This research also found that the study on CRM is still dearth. There is rare literature on CRM and only relationship between CRM and MP. This study is contributing to the literature 
on the relationship of CRM and MP. Finally, the literature on the moderation effect on TMS on the relationship between CRM and MP are having contradiction, whereby according to Rajput et al. (2018) TMS does not moderate the relationship between customer relationship management and new product performance, and according to Yang and Zhang (2018) TMS does not moderate the relationship between customer focus and non-financial performance, meanwhile according to Beitelspacher et al. (2012) TMS moderates the relationship between customer orientation and market performance. The study found the contradiction (gap) in the literature study.

\section{Contextual Contribution}

The definition of CRM is a combination of operational definition from Terho and Jalkala (2017) and Kilian et al. (2013). Terho and Jalkala (2017) defined the CRM in the context of ICT, healthcare, financials and industrial (process technology equipment business) in Finland. And, Kilian et al. (2013) defined the CRM in the context of mechanical engineering industry in German. Hence, the operational definition is operable in ICT, healthcare, financials, industrial (process technology equipment business) and mechanical engineering industry. The contradiction of the literature on moderation effect of TMS on the relationship between CRM and MP of which is defined by Rajput et al. (2018) with the context ISO certified firms of several industries such as food, banking, textile, pharmaceuticals, and footwear found no moderation effect of TMS on the relatioship between customer relationship management and new product performance. Besides, Yang and Zhang (2018) with the context of electronics, machinery and transportation components in Brazil, China, Finland, Germany, Israel, Italy, Japan, South Korea, Spain, Sweden, and Taiwan found no moderation effect of TMS on the relationship between customer focus and non-financial performance. Meanwhile, Beitelspacher et al. (2012) with the context retail supply chain in USA found that is moderation effect of TMS on the relationship between customer orientation and market performance. Thus, based on the above literature TMS has the moderation effect between CRM and MP in the context of retail supply chain in USA. And, TMS has no moderation effect of TMS on the relationship between CRM and MP in the context of food, banking, textile, pharmaceuticals, footwear, electronics, machinery and transportation components.

\section{Limitation of the Research}

This conceptual paper has MP as dependent variable, CRM as predictor, and TMS as moderator. The literature are collected from some journals namely Emerald, Elsevier, JSTOR, ScienceDirect, Google Scholars, and Scopus journals. Besides, the literature were collected from approximately five years period back from 2019 as the following; firstly, MP variable and definitions, linkage between CRM and MP were collected within the period of 2014-2018, secondly, CRM variable and definitions, literature were collected within the period of 20132018, and finally, TMS variable and definitions, and TMS as moderating variable on the relationship between CRM and MP, literature were collected within the period 2012- 2018.

According to ToP, MP has two dimensions they are financial and non-financial dimensions. However in this study, the researchers limit the dimension only to non-financial for MP variable due to non-financial measures are becoming prerequisite measure of financial dimension of organization. Meanwhile Damanpour et al. (2009) stated that the performance with non-financial in firms embrace innovation to gain a competitive advantage that will ultimately lead to superior performance. 
The underpinning theory of this study is RBV. According to RBV, this theory consisting of many internal factors of organization. However, this study limits only to three internal factors, they are MP, CRM and TMS. The relationship between CRM and MP is in accordance with the recommendation by Terho and Jalkala (2017), and there is contradiction on the moderating effect of TMS on the relationship between CRM and performances.

This study is a conceptual paper and subject to be continued with data processing and the hypotheses results.

\section{References}

Aarikka-Stenroos, L., \& Makkonen, H. S. (2014). Industrial buyers' use of references, word-ofmouth and reputation in complex buying situation. Journal of Business and Industrial Marketing, 29(4), 344-352. https://doi.org/10.1108/JBIM-08-2013-0164

Ahmad, A. C., \& Jusoh, M. A. (2014). Institutional Ownership and Market-based Performance Indicators: Utilizing Generalized Least Square Estimation Technique. Procedia - Social and Behavioral Sciences, 164(August), 477-485. https://doi.org/10.1016/j.sbspro.2014.11.105

Ahmed, R., \& Mohamed, A. B. N. (2016). Exploring the relationship between multidimensional top management support and project success: An international study. EMJ - Engineering Management Journal, 28(1), 54-67. https://doi.org/10.1080/10429247.2015.1136525

Ahmed, R., \& Mohamed, A. B. N. (2017). Development and validation of an instrument for multidimensional top management support. International Journal of Productivity and Performance Management, 66(7), 873-895. https://doi.org/10.1108/IJPPM-12-2015-0182

Aksoy, H. (2017). How do innovation culture, marketing innovation and product innovation affect the market performance of small and medium-sized enterprises (SMEs). Technology in Society, 133-141. https://doi.org/10.1016/j.techsoc.2017.08.005

Al Shaar, E. M., Khattab, S. A., Alkaied, R. N., \& Manna, A. Q. (2015). The Effect of Top Management Support on Innovation: the Mediating Role of Synergy Between Organizational Structure and Information Technology. International Review of Management and Business Research, 4(2), 499-513.

Alam, M. G. R., Masum, A. K. M., Beh, L. S., \& Hong, C. S. (2016). Critical factors influencing decision to adopt human resource information system (HRIS) in hospitals. PLOS ONE, 11(8), 1-23. https://doi.org/10.1371/journal.pone.0160366

Almahamid, S., \& Awsi, O. (2015). Perceived organizational ERP benefits for SMEs: Middle eastern perspective. Interdisciplinary Journal of Information, Knowledge, and Management, 10, 145-172. https://doi.org/10.28945/2301

Alqahtani, F. H. (2017). The acceptance of corporate wiki use for knowledge diffusion purposes. Aslib Journal of Information Management, 69(6), 642-659. https://doi.org/10.1108/AJIM-04-2017-0088

Alvarez, S. A., \& Barney, J. B. (2007). Discovery and Creation: Alternative Theories of Enterpreneurial Action. Strategic Entrepreneurship Journal, 1(1-2), 11-26. https://doi.org/10.1002/sej

Ambrosini, V., Bowman, C., \& Collier, N. (2009). Dynamic capabilities: An exploration of how firms renew their resource base. British Journal of Management, 20(9-24). 
https://doi.org/10.1111/j.1467-8551.2008.00610.x

Anderson, J. C., Narus, J. A., \& Rossum, W. V. (2006). Customer Value Propositions in Business. Harvard Business Review, 1-11.

Anderson, J. C., \& Wynstra, F. (2010). Purchasing higher-value, higher-price offerings in business markets. Journal of Business-to-Business Marketing, 17(1), 29-61. https://doi.org/10.1080/10517120903000363

Ballantyne, D., Frow, P., Varey, R. J., \& Payne, A. (2011). Value propositions as communication practice: Taking a wider view. Industrial Marketing Management, 40(2), 202-210.

https://doi.org/10.1016/j.indmarman.2010.06.032

Barney, J. B., Ketchen Jr, D. J., \& Wright, M. (2011). The future of resource-based theory: Revitalization or decline? Journal of Management, 37(5), 1299-1315. https://doi.org/10.1177/0149206310391805

Barney, J. (1991). Firm Resources and Sustained Competitive Advantage. Journal of Management, 17(1), 99-120. https://doi.org/10.1177/014920639101700108

Beitelspacher, L. S., Tokman, M., Adams, F. G., \& R. Glenn Richey, J. (2012). Retail servicebased operant resources and market performance. International Journal of Logistics Management, 23(3), 408-434. https://doi.org/10.1108/09574091211289246

Birken, S. A., Lee, S. Y. D., Weiner, B. J., Chin, M. H., Chiu, M., \& Schaefer, C. T. (2015). From strategy to action: How top managers' support increases middle managers' commitment to innovation implementation in health care organizations. Health Care Management Review, 40(2), 159-168.

https://doi.org/10.1097/HMR.0000000000000018

Bruni, D. S., \& Verona, G. (2009). Dynamic marketing capabilities in science-based firms: An exploratory investigation of the pharmaceutical industry. British Journal of Management, 20(101-117). https://doi.org/10.1111/j.14678551.2008.00615.x

Bueno, S., \& Gallego, M. D. (2017). Managing top management support in complex information systems projects: An end-user empirical study. Journal of Systems and Information Technology, 19(1-2), 151-164. https://doi.org/10.1108/JSIT-06-2017-0043

Butt, F. S., Nawab, S., \& Zahid, M. (2018). Organizational Factors and Individual Effectiveness : Moderating Role of Change Management Faisal Shafique Butt, Samina Nawab and Mohsin Zahid, 33(1), 75-100.

Candi, M. (2016). Technovation Contributions of design emphasis, design resources and design excellence to market performance in technology-based service innovation. Technovation, 55-56, 33-41. https://doi.org/10.1016/j.technovation.2016.05.004

Chizari, M. hosein, Mehrjardi, R. Z., Sadrabadi, M. M., \& Mehrjardi, F. K. (2016). The impact of Intellectual Capitals of Pharmaceutical Companies Listed in Tehran Stock Exchange on their Market Performance. Procedia Economics and Finance, 36(16), 291-300. https://doi.org/10.1016/s2212-5671(16)30040-5

Dabari, I. J., \& Saidin, S. Z. (2014). A Theoretical Framework on the Level of Risk Management Implementation in the Nigerian Banking Sector: The Moderating Effect of Top Management Support. Procedia - Social and Behavioral Sciences, 164, 627-634. https://doi.org/10.1016/j.sbspro.2014.11.156

Dai, J., Montabon, F. L., \& Cantor, D. E. (2014). Linking rival and stakeholder pressure to green 
supply management: Mediating role of top management support. Transportation Research Part E: Logistics and Transportation Review, 74, 173-187. https://doi.org/10.1016/j.tre.2014.12.003

Damanpour, F., Walker, R. M., \& Avellaneda, C. N. (2009). Combinative effects of innovation types and organizational Performance: A longitudinal study of service organizations. Journal of Management Studies, 46(4), 650-675. https://doi.org/10.1111/j.14676486.2008.00814.x

Elger, D. (2007). Theory of performance. Faculty guidebook: A comprehensive tool for improving faculty performance, 1, 19-22. Pacific Crest.

Faber, S., Geenhuizen, V. M., \& Reuver, D. M. (2017). eHealth adoption factors in medical hospitals: A focus on the Netherlands. International Journal of Medical Informatics, 100, 77-89. https://doi.org/10.1016/j.ijmedinf.2017.01.009

Fang, E. E., \& Zou, S. (2009). Antecedents and consequences of marketing dynamic capabilities in international joint ventures. Journal of International Business Studies, 40(5), 742-761. https://doi.org/10.1057/jibs.2008.96

Feng, T., \& Zhao, G. (2014). Top management support, inter-organizational relationships and external involvement. Industrial Management and Data Systems, 114(4), 526-549. https://doi.org/10.1108/IMDS-03-2013-0127

García-Sánchez, E., García-Morales, V. J., \& Bolívar-Ramos, M. T. (2015). The influence of top management support for ICTs on organisational performance through knowledge acquisition, transfer, and utilisation. Review of Managerial Science, 11(1), 19-51. https://doi.org/10.1007/s11846-015-0179-3

García-Sánchez, E., Guerrero-Villegas, J., \& Aguilera-Caracuel, J. (2018). How do technological skills improve reverse logistics? The moderating role of top management support in information technology use and innovativeness. Sustainability (Switzerland), 11(1), 58. https://doi.org/10.3390/su11010058

Hamdi, S., Silong, A. D., Omar, B. Z., \& Rasdi, R. M. (2016). Impact of T-shaped skill and top management support on innovation speed; the moderating role of technology uncertainty. Cogent Business and Management, 3(1).

https://doi.org/10.1080/23311975.2016.1153768

Hitt, M. A., Carnes, C. M., \& Xu, K. (2016). A current view of resource based theory in operations management: A response to Bromiley and Rau. Journal of Operations Management, 41(1), 107-109. https://doi.org/10.1016/j.jom.2015.11.004

Hsu, H. Y., Liu, F. H., Tsou, H. T., \& Chen, L. J. (2018). Openness of technology adoption, top management support and service innovation: a social innovation perspective. Journal of Business and Industrial Marketing, 19(2), 150-166. https://doi.org/10.1108/JBIM-032017-0068

Hunt, S. D., \& Mogan, R. M. (1995). The Comparative Advantage Theory of Competition. Journal of Marketing, 59, 1-15.

Iqbal, S. M. J., Long, C. S., Fei, G. C., \& Bukhari, S. M. L. A. B. S. (2015). Moderating Effect of Top Management Support on Relationship between Transformational Leadership and Project Success. Pakistan Journal of Commerce and Social Sciences, 9(2), 540-567.

Jalkala, A., \& Salminen, R. T. (2010). Practices and functions of customer reference marketing - Leveraging customer references as marketing assets. Industrial Marketing Management, 39(6), 975-985.

https://doi.org/10.1016/j.indmarman.2010.06.017 
Jia, J., \& Capretz, L. F. (2018). Direct and mediating influences of user-developer perception gaps in requirements understanding on user participation. Requirements Engineering, 23(2), 277-290. https://doi.org/10.1007/s00766-017-0266-x

John, W. (2018). Scale Development and Construct Validity of Organizational Capital in Customer Relationship Management Context: A Confirmatory Factor Analysis Approach. Business Perspectives and Research, 7(1), 76-91. https://doi.org/10.1177/2278533718800600

Josiassen, A., Assaf, A. G., \& Cvelbar, L. K. (2014). CRM and the bottom line: Do all CRM dimensions affect firm performance? International Journal of Hospitality Management, 36, 130-136. https://doi.org/10.1016/j.ijhm.2013.08.005

Kaleka, A., \& Morgan, N. A. (2017). How marketing capabilities and current performance drive strategic intentions in international markets. Industrial Marketing Management.

Kanwal, N., Zafar, M. S., \& Bashir, S. (2017). The combined effects of managerial control, resource commitment, and top management support on the successful delivery of information systems projects. International Journal of Project Management, 35(8), 1459-1465.

https://doi.org/10.1016/j.ijproman.2017.08.007

Kilian, T., Greuling, K., \& Hennigs, N. (2013). Communicating Competency in References: A Qualitative Analysis of the Utilization of References in Mechanical Engineering. Journal of Business-to-Business Marketing, 20(2), 65-79.

https://doi.org/10.1080/1051712X.2012.719180

Kohli, A. K., \& Jaworski, B. J. (1990). Market Orientation: The Construct, Research Propositions, and Managerial Implications. Journal of Marketing, 54(2), 1-18.

Kozlenkova, I. V., Samaha, S. A., \& Palmatier, R. W. (2014). Resource-based theory in marketing. Journal of the Academy of Marketing Science, 42(1), 1-21. https://doi.org/10.1007/s11747-013-0336-7

Lee, J. C., Shiue, Y. C., \& Chen, C. Y. (2016). Examining the impacts of organizational culture and top management support of knowledge sharing on the success of software process improvement. Computers in Human Behavior, 54, 462-474. https://doi.org/10.1016/j.chb.2015.08.030

Lim, S. A. H., \& Antony, J. (2016). Statistical process control readiness in the food industry: Development of a self-assessment tool. Trends in Food Science and Technology, 58, 133139. https://doi.org/10.1016/j.tifs.2016.10.025

Masum, A. K. M. (2015). Adoption Factors of Electronic Human Resource Management (eHRM) in Banking Industry of Bangladesh. Journal of Social Sciences, 11(1), 1-6. https://doi.org/10.3844/jssp.2015.1.6

Melnyk, S. A., Bititci, U., Platts, K., Tobias, J., \& Andersen, B. (2013). Is performance measurement and management fit for the future? Management Accounting Research, 173-186. https://doi.org/10.1016/j.mar.2013.07.007

Menguc, B., \& Auh, S. (2006). Creating a firm-level dynamic capability through capitalizing on market orientation and innovativeness. Journal of the Academy of Marketing Science, 34(1), 63-73. https://doi.org/10.1177/0092070305281090

Mohtaramzadeh, M., Ramayah, T., \& Jun-Hwa, C. (2017). B2B E-Commerce Adoption in Iranian Manufacturing Companies: Analyzing the Moderating Role of Organizational Culture. International Journal of Human-Computer Interaction, 34(7), 621-639. https://doi.org/10.1080/10447318.2017.1385212 
Morgado, A. V. (2018). The Value of Customer References to Potential Customers in Business Markets. Journal of Creating Value, 4(1), 132-154.

https://doi.org/10.1177/2394964318771799

Morgado, A. V., \& de Castro, L. M. (2016). Customer references and the buying of capital equipment for a project firm. Journal of Strategic Contracting and Negotiation, 2(3), 244-263. https://doi.org/10.1177/2055563616684162

Morgan, R. M., \& Hunt, S. (1999). Relationship-Based Competitive Advantage: The Role of Relationship Marketing in Marketing Strategy. Journal of Business Research, 46(3), 281290. https://doi.org/10.1016/S0148-2963(98)00035-6

Nguyen, B., Yu, X., Melewar, T. C., \& Gupta, S. (2016). Critical brand innovation factors (CBIF): Understanding innovation and market performance in the Chinese high-tech service industry. Journal of Business Research, 69(7), 2471-2479.

https://doi.org/10.1016/j.jbusres.2016.02.016

Pasamehmetoglu, A., Guchait, P., Tracey, J. B., Cunningham, C. J. L., \& Lei, P. (2017). The moderating effect of supervisor and coworker support for error management on service recovery performance and helping behaviors. Journal of Service Theory and Practice, 27(1), 2-22. https://doi.org/10.1108/JSTP-06-2015-0130

Payne, A., \& Frow, P. (2005). A Strategic Framework for Customer Relationship Managemen. Journal of Marketing, 69(4), 167-176.

Pino, C., Felzensztein, C., Zwerg-Villegas, A. M., \& Arias-Bolzmann, L. (2016). Nontechnological innovations: Market performance of exporting firms in South America. Journal of Business Research, 69(10), 4385-4393.

https://doi.org/10.1016/j.jbusres.2016.03.061

Prieto-Pastor, I., \& Martin-Perez, V. (2015). Does HRM generate ambidextrous employees for ambidextrous learning? The moderating role of management support. International Journal of Human Resource Management, 26(5), 589-615. https://doi.org/10.1080/09585192.2014.938682

Rahikkala, J., Leppänen, V., Ruohonen, J., \& Holvitie, J. (2015). Top management support in software cost estimation. International Journal of Managing Projects in Business, 8(3), 513-532. https://doi.org/10.1108/ijmpb-11-2014-0076

Rajput, A., Zahid, M. M., \& Najaf, R. (2018). Using CRM to Model Firm Performance in a Business-to-Business Market. Journal of Relationship Marketing, 17(2), 118-151. https://doi.org/10.1080/15332667.2018.1440142

Reinartz, W., Krafft, M., \& Hoyer, W. D. (2004). The Customer Relationship Management Process: Its Measurement and Impact on Performance. Journal of Marketing Research, XLI(3), 293-305. Roach, D., Ryman, J., Jones, R., \& Ryman, H. (2018). Enhancing Innovativeness: The Role of Dynamic Marketing Capabilities. Canadian Journal of Administrative Sciences, 35(4), 563-576. https://doi.org/10.1002/cjas.1473

Roach, D., Ryman, J., Jones, R., \& Ryman, H. (2018). Enhancing Innovativeness: The Role of Dynamic Marketing Capabilities. Canadian Journal of Administrative Sciences/Revue Canadienne des Sciences de l'Administration, 35(4), 563-576. https://doi.org/10.1002/cjas.1473

Ruokolainen, J., \& Aarikka-Stenroos, L. (2016). Rhetoric in customer referencing: Fortifying sales arguments in two start-up companies. Industrial Marketing Management, 54, 188202. https://doi.org/10.1016/j.indmarman.2015.08.002

Salminen, R. T. (2001). Success factors of a reference visit - A single case study. Journal of 
Business and Industrial Marketing, 16(6-7), 487-507. https://doi.org/10.1108/08858620110403086

Salminen, R. T., \& Möller, K. (2006). Role of References in Business Marketing - Towards a Normative Theory of Referencing. Journal of Business-to-Business Marketing, 13(1), 151.

Salminen, R. T., \& Möller, K. E. (2004). Use of References in Industrial Bidding - A Decision Process Analysis. Journal of Marketing Management, 20(1-2), 133-156. https://doi.org/10.1362/026725704773041159

Santos-Vijande, M. L., López-Sánchez, J. Á., \& Pascual-Fernández, P. (2015). Co-creation with clients of hotel services: the moderating role of top management support. Current Issues in Tourism, 21(3), 301-327.

https://doi.org/10.1080/13683500.2015.1078781

Seyoum, B., \& Lian, Y. (2018). Market performance implications of modularization : Evidence from global auto fi rms operating in China. International Business Review, 27(4), 852866. https://doi.org/10.1016/j.ibusrev.2018.01.008

Shee, H., Miah, S. J., Fairfield, L., \& Pujawan, N. (2018). The impact of cloud-enabled process integration on supply chain performance and firm sustainability: the moderating role of top management. Supply Chain Management: An International Journal, 23(6), 500-517. https://doi.org/10.1108/SCM-09-2017-0309

Sheikh, A. A., Shahzad, A., \& Ishak, A. ku. (2017). The Impact of Market Orientation, Top Management Support, Use of E-Marketing and Technological Opportunism on the Firm Performance: A Mediated-Moderation and Moderated-Mediation Analysis. Abasyn Journal of Social Sciences, 10(2), 212-234.

Stirpe, L., Bonache, J., \& Trullen, J. (2015). The acceptance of newly introduced HR practices some evidence from spain on the role of management behavior and organizational climate. International Journal of Manpower, 36(3), 334-353.

https://doi.org/10.1108/IJM-10-2012-0155

Terho, H., Haas, A., Eggert, A., \& Ulaga, W. (2012). 'It's almost like taking the sales out of selling'-Towards a conceptualization of value-based selling in business markets. Industrial Marketing Management, 41(1), 174-185.

https://doi.org/10.1016/j.indmarman.2011.11.011

Terho, H., \& Jalkala, A. (2017). Customer reference marketing: Conceptualization, measurement and link to selling performance. Industrial Marketing Management, 64, 175-186. https://doi.org/10.1016/j.indmarman.2017.01.005

Ulaga, W., \& Reinartz, W. J. (2011). Hybrid Offerings: How Manufacturing Firms Combine Goods and Services Successfully. Journal of Marketing, 75(6), 5-23. https://doi.org/10.1509/jm.09.0395

Wang, G., \& Song, J. (2017). The relation of perceived benefits and organizational supports to user satisfaction with building information model (BIM). Computers in Human Behavior, 68, 493-500. https://doi.org/10.1016/j.chb.2016.12.002

Wangui, K. A., Faith, O. A., \& Aketch, N. 'ong 'a E. (2019). Strategies to Improve Performance Adopted By Social Enterprises in Kenya. International Journal of Academic Research Business and Social Sciences, 9(5), 39-64. https://doi.org/10.6007/IJARBSS/v9-i5/5840

Winter, S. G. (2003). Understanding dynamic capabilities. Strategic Management Journal, 24(10), 991-995. https://doi.org/10.1002/smj.318

Yang, F., \& Zhang, H. (2018). The impact of customer orientation on new product 
development performance: The role of top management support. International Journal of Productivity and Performance Management, 67(3), 590-607.

https://doi.org/10.1108/IJPPM-08-2016-0166

Young, R., \& Jordan, E. (2008). Top management support: Mantra or necessity? International Journal of Project Management, 26(7), 713-725.

https://doi.org/10.1016/j.ijproman.2008.06.001

Yunus, S., Jailani, S. F. A. K., Hairuddin, H., \& Kassim, E. S. (2013, November). Green IT adoption towards environmental sustainability: The moderating role of top management enforcement. In 2013 International Conference on Research and Innovation in Information Systems (ICRIIS) (pp. 241-244). IEEE. https://doi.org/10.1109/ICRIIS.2013.6716716

Zhang, Y., Wei, Y., \& Zhou, G. (2018). Promoting firms' energy-saving behavior: The role of institutional pressures, top management support and financial slack. Energy Policy, 115, 230-238. https://doi.org/10.1016/j.enpol.2018.01.003

Zhu, Q., Zou, F., \& Zhang, P. (2019). The role of innovation for performance improvement through corporate social responsibility practices among small and medium-sized suppliers in China. Corporate Social Responsibility and Environmental Management, 26(2), 341-350. https://doi.org/10.1002/csr.1686 